\title{
THE ROLE OF INTERNAL FINANCING IN MEDIATING THE EFFECT OF MANAGERIAL OVERCONFIDENCE AND CORPORATE GOVERNANCE TOWARDS INVESTMENT EFFICIENCY
}

\author{
Riski Amalia Madi ${ }^{*}$, Sujono ${ }^{2}$, Hamrini $^{3}$ Enny wati ${ }^{4}$ \\ ${ }^{1,2,3,3,}$ Faculty of Economics and Business, University of Halu Oleo \\ Email: 1 ${ }^{*}$ riski amalia98@yahoo.com, ${ }^{2}$ drsujono111@gmail.com, \\ 3hamrinimutia@gmail.com, ennywati75@gmail.com ${ }^{4}$ \\ *Corresponding author
}

\begin{abstract}
This study aims to examine empirically the factors that influence investment efficiency in State-Owned Enterprises on the Indonesia Stock Exchange. This study was tested with two independent variables are managerial overconfidence and corporate governance, intervening variable is internal financing. The object of this research is the state-owned company for the period 2011-2018. 10 companies as the sample using purposive sampling technique. The analysis used in this research is panel data regression analysis. The results of this study found that investment efficiency in state-owned enterprises in Indonesia is largely determined by managerial overconfidence bias. Managers who have an overconfidence seek more aggressive and risky ventures so that they invest excessively beyond optimal levels. Managerial overconfidence in a manager can also strengthen the choice of internal financing, especially in state-owned companies. However, investment efficiency in this study is not influenced by corporate governance and internal financing. Corporate governance has also proven to have no role in corporate funding decisions. The role of internal financing as mediation was not found in this study.
\end{abstract}

Keywords: internal financing, managerial overconfidence, corporate governance, investment efficiency.

\section{Introduction}

Investment is important for company survival, market competition and value creation (He et al., 2019). However, investment needs to be formulated carefully because investment is determined by various factors. These factors are: economic factors, monetary factors, capital market factors and company operating factors (Richardson, 2006). Apart from these factors, psychological factors also play an important role in investment policy (Kahneman \& Lovallo, 1993; Goel \& Thakor, 2000; Shefrin, 2001; Heaton, 2002, Gervais, Heaton and Odean, 2002; Hackbarth, 2003). One of the psychological factors that get the attention of the research is overconfidence. Oveconfidence at the practical level is often referred to as optimism bias. Thus the economic factors, Fundamental factors and psychological factors play an important role for the survival of the company, market competition and value creation. This means that fundamental factors, economic factors and psychological factors determine the company's investment.

State-owned enterprises have contributed significantly to the capital market, with market capitalization contributing $25.2 \%$ of the total market capitalization on the Indonesia Stock Exchange (IDX). This achievement is certainly very encouraging considering that the number of BUMNs that list their shares on the IDX is only around $4 \%$, namely 20 (twenty) companies and 6 (six) BUMN subsidiaries of the total Issuers on the IDX, which reaches 538 companies. In addition, there are 4 (four) BUMN issuers included in the 10 (ten) issuers with the largest market capitalization, namely Telkom, BRI, Bank Mandiri, and BNI.

In 2017, the total capital expenditure of BUMN reached Rp. 301 trillion, an increase from the achievement of BUMN capital expenditure in 2016 which reached Rp. 298 trillion. The largest increase in the number of Capex was contributed by BUMN in the construction sector, the electricity sector and the transportation and warehousing sector. Meanwhile, state-owned companies that contributed the most to the increase were PT Perusahaan Listrik Negara (Persero), PT Waskita Karya (Persero) Tbk and PT Jasa Marga (Persero) Tbk. However, based on data in 2017, the target of BUMN Capex Total of 468 trillion has not been achieved (Ministry of BUMN 2018).

The absence of the BUMN capex target is interesting to study. The factors that cause the target not to be achieved can be caused by managerial factors, funding factors and governance factors. Managerial factors that are widely studied by 
academics are psychological factors, especially overconfidence. A summary of several studies with contradictory findings can be seen in Table 1

Table 1

Research on Corporate Governance, Managerial Overconfidence, Internal Financing, Investment Efficiency

\begin{tabular}{|c|c|c|c|}
\hline No. & Research Gap & Findings & Author \\
\hline \multirow{5}{*}{1.} & There is a contradiction in & \multirow{4}{*}{-* } & Heaton $\quad$ (2002), \\
\hline & the findings of the influence & & Malmendier $\quad$ Tate \\
\hline & of Managerial & & (2005); Xia et al. \\
\hline & Overconfidence on & & (2009), He et al. (2019) \\
\hline & Investment Efficiency & + & Chen, Lin (2012) \\
\hline & $\begin{array}{l}\text { There is a contradiction in } \\
\text { the findings of the influence }\end{array}$ & + & $\begin{array}{l}\text { Huang et al. } \\
\text { Boubaker, }\end{array}$ \\
\hline \multirow[t]{4}{*}{2.} & of Managerial & & (2014), Murhadi (2018) \\
\hline & Overconfidence on Internal & - & Rihab, Lotfi (2016) \\
\hline & Financing & $+*$ & Ting et al. (2016) \\
\hline & $\begin{array}{l}\text { There is a contradiction in } \\
\text { the findings of the influence }\end{array}$ & + & $\begin{array}{l}\text { Al-Najjar, Clark (2007), } \\
\text { Arping, Sautner (2010), } \\
\text { Yapono (2018) }\end{array}$ \\
\hline 3. & $\begin{array}{l}\text { of Governance on Internal } \\
\text { Financing }\end{array}$ & - & $\begin{array}{l}\text { Daud (2011), Grosman } \\
\text { (2012) }\end{array}$ \\
\hline \multirow{3}{*}{4.} & There is a contradiction in & + & $\begin{array}{l}\text { Santi et al. (2014), Qian } \\
\text { et al. (2014) }\end{array}$ \\
\hline & Governance on & - & Chen et al. (2017) \\
\hline & $\begin{array}{l}\text { Governance on } \\
\text { Efficiency }\end{array}$ & & $\begin{array}{l}\text { Salin et al. (2018), } \\
\text { Azhar et al. (2019) }\end{array}$ \\
\hline \multirow[t]{2}{*}{5.} & $\begin{array}{l}\text { There is a contradiction in } \\
\text { the findings of the influence }\end{array}$ & & $\begin{array}{l}\text { Mohamed et al. (2014), } \\
\text { Liu, Mu, Wen (2016), } \\
\text { Moez, Amina (2017) }\end{array}$ \\
\hline & $\begin{array}{l}\text { of Internal Financing on } \\
\text { Investment Efficiency }\end{array}$ & + & $\begin{array}{l}\text { Shima, Nakamura } \\
(2018), \text { He et al. }(2019)\end{array}$ \\
\hline
\end{tabular}

Source: Research Elaboration Results, 2020

There were many gaps in research findings that occurred in previous studies, perhaps due to differences in models. In this connection, this study proposes a structural model by adding a governance variable as a follow-up to the research suggestions of $\mathrm{He}$ et al. (2019) which suggest studying governance in shaping investment efficiency capital. On the basis of these considerations, the authors raised the title: "The Role of Internal Financing in Mediating the Effect of Managerial Overconfidence and Corporate Governance on Investment Efficiency".

Based on the background above, this research aims to Assessing the effect of managerial overconfidence on investment efficiency, managerial overconfidence on Internal Financing, Corporate Governance on Internal Financing, Governance on Investment Efficiency, Internal Financing on Investment Efficiency, Internal Financing as a mediation for the influence of managerial overconfidence on Investment Efficiency, and Internal Financing as a mediation for the influence of Governance on Investment Efficiency.

\section{Theoretical Basis}

The theoretical basis is important in research as a basis for testing hypotheses. The elements of theory are a set of concepts, definitions and propositions that are arranged systematically which can then be used to explain or predict existing phenomena (Cooper and Schlinder, 2003). In this study, the variables studied were overconfidence, governance, internal financing, and investment. Based on the variables studied, the theory used is the theory of: overconfidence, governance theory, capital structure theory.

\section{Overconfidence Theory}

Based on the psychological literature, overconfidence can be interpreted as the belief that the distribution of a person's prediction probability is higher than it actually is, whereas in various financial literatures, overconfidence is defined as overestimating in assessing a financial asset. The empirical research conducted by Griffin \& Varey (1996) states that overconfidence is divided into two types, namely someone who is overconfidence because he is too confident in his knowledge and because he is too confident in his own abilities.

\section{Agency Theory (Agency Theory)}

The development of corporate governance departs from the agency theory developed by Jensen and Meckling in 1976. This theory argues that "agency relationship as a contract under which one or more persons (the principals) engage another person (the agent) to perform some service on their behalf which involves delegating some decision making authority to the agent". The principal or company owner hands over the management of the company to the management.

\section{Board of Commissioners}

According to the Limited Liability Company Law Number 40 of 2007 paragraph 6 in Agoes and Ardana (2014: 108) the board of commissioners is as follows:

"The board of commissioners is an organ of the company that is tasked with conducting general and / or specific supervision in accordance with the articles of association and providing advice to the directors".

In this study, the board of commissioners indicators were measured by the number of board meetings. Board meetings are a medium for deliberation on key issues and other important matters among board members in order to make certain important decisions for the progress and growth of each organization (Eluyela et al., 2018). In order 
to carry out its duties, the board of commissioners holds regular meetings to evaluate policies taken by the board of directors.

\section{Capital Structure Theory}

The capital structure is a mix of long-term debt and equity funding (Brealey et al., 2011: 600). Capital structure is a company way to form the right side of a balance sheet consisting of capital and debt (Zani et.al., 2013). The capital structure consists of short-term funding, long-term funding, and equity.

\section{Theory Modigliani-Miller (MM)}

Modigliani and Miller's theory (MM theory) is a theory which holds that capital structure is irrelevant or does not affect firm value.

\section{Investment Efficiency Concept}

Efficiency is an action to use resources appropriately so that existing resources are not wasted. Companies usually make efficiency in order to reduce costs and facilitate the process of managing the company in order to easily achieve company goals. A company is said to invest efficiently if it takes projects that have a positive net present value (NPV) in conditions where there is no market friction such as adverse selection or agency costs (Biddle et al., 2009).

\section{Conseptual Frame Work}

This study examines managerial overconfidence and corporate governance as independent variables associated with investment efficiency as the dependent variable and internal funding as an intervening variable.

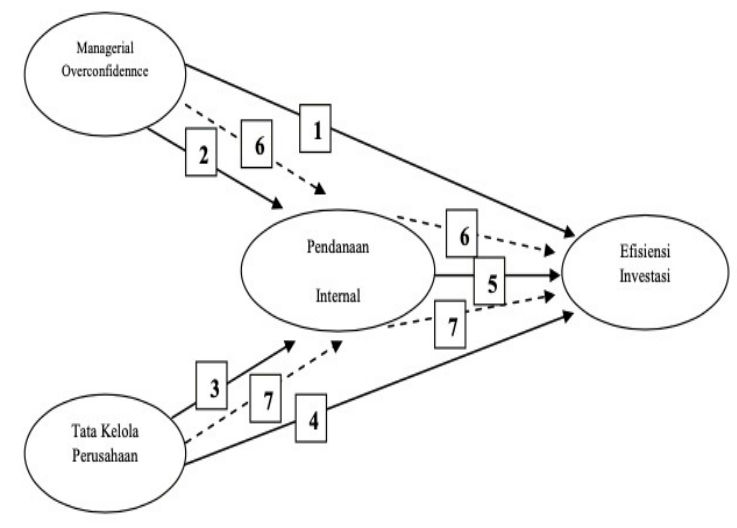

Figure 1 Conceptual Frame Work

\section{Research Hypothesis}

\section{Effect of Managerial Overconfidence on Investment Efficiency}

Managerial overconfidence is a cognitive bias that drives managers to believe that they are capable of doing better than the average person (Kidd 1970; Larwood Whittaker 1977; Moore 1977; Svenson 1981; Alicke 1985; Camerer Lavallo 1999). Their overestimation and judgment leads managers to seek more aggressive ventures and risk overinvesting beyond optimal levels.

Investment is said to be efficient if it is not in 2 conditions, namely underinvestment and overinvestment. Underinvestment is defined as missing an investment opportunity that would result in a positive NPV in the absence of adverse selection. Accordingly, overinvestment is defined as investing in projects with a negative NPV (Biddle et al., 2009).

Chen et al. (2012) in his research found that underinvestment companies with CEOs who have a high level of managerial optimism can increase the company's investment efficiency by reducing the level of underinvestment, and will increase firm value. However, there is a negative and significant relationship between managerial trust and investment efficiency empirically shown by Heaton (2002); Malmendier Tate (2005); and Xia et al. (2009). Manager's choice for Suboptimal levels of investment may stem from the CEO's overestimation of investment (Heaton, 2002 and Malmendier Tate, 2005). In line with the research conducted by $\mathrm{He}$ et al. (2019) found that managerial overconfidence causes overinvestment problems, especially in state-owned companies. Based on this explanation, the hypotheses built in this study are;

H1 : Managerial overconfidence has a negative and significant effect on investment efficiency

\section{Effect of Managerial Overconfidence on Internal Funding}

Managerial overconfidence is one of the behavioral biases in which managers act irrationally which tends to reflect excessive self-confidence, because they judge their abilities better than 
most people. So they tend to exaggerate their own wisdom (Larwood and Whittaker, 1997; Svenson, 1981; Alicke, 1985). (Heaton 2002) supports this over-optimism and overconfidence. The results show that agents easily become optimistic because they believe they are controlling and highly committed. This "better than average" impact is easily extended to economic decision making (Camerer and Dan, 1999).

Pecking Order Theory argues that companies will prioritize funding sources on the basis of their costs. Graham and Harvey (2001) show that most managers believe that they have the ability to control funding decisions and influence business performance. Manager's personal wealth and human capital are closely related to fluctuations in the company's stock price. From their personal perspective, managers prefer internal funding because it is the lowest cost of capital and limits fluctuations from external borrowing markets and stock markets.

Managerial overconfidence tends to have the illusion of control over technology and the accuracy of their own judgments. When making decisions, overconfident managers tend to overestimate the likelihood of success. They also believe that their company will show good profits and have great potential. In addition, they think that outside investors underestimate their actual value. Due to information asymmetry and transaction costs, managers tend to prefer internal funding and residual cash inside. Similar to BenDavid et al. (2007) found that CEO confidence shows that they are less likely to pay dividends, this supports the view that overconfident managers prefer internal funding by reducing dividends.

Huang et al. (2010) in his research found that agency costs have a positive and significant effect between the overconfidence of top executives on the use of cash flows. However, research conducted by Rihab et al. (2016) found different results, namely managerial overconfidence has a positive and significant effect on the level of debt use.

While the research conducted by Boubaker et al. (2014) stated that in the face of growth opportunities, managerial overconfidence negatively affects the leverage ratio. Supporting these findings Ting et al. (2016) in his research stated that $\mathrm{CEO}$ overconfidence has a negative and significant effect on corporate debt financing. Based on this explanation, the hypotheses built in this study are;

H2: Manager overconfidence has a positive and significant effect on internal funding

\section{The Effect of Corporate Governance on Internal Funding}

Agency theory developed by Jensen \& Meckling (1976) explains the agency relationship between agents and principals. In this case, the agent as the manager of the company must be responsible for the form of its management to the principal. One of his responsibilities is managing the company's funding source decisions. Funding decisions are important things that need to be considered by managers when managing the company's funding structure that comes from internal funding sources and external funding sources. Pecking Order Theory according to Myers \& Majluf (1984) explains the hierarchy of the company's funding sources, namely internal sources of funds, debt and the issuance of shares.

The mechanism of corporate governance is a factor influencing the decision to choose the company's funding source, where management tends to minimize the company's debt level (Yapono, 2018). The number of meetings of the board of commissioners is one that plays a role in the mechanism of corporate governance.

Regular meetings will increase the effectiveness of the board of commissioners in carrying out its supervisory role over the financial reporting process and internal control. The results of research conducted by Juwitasari (2008) which states that regular and well-controlled meetings will assist the board of commissioners in conducting supervision and are better able to offer criticism in relation to the policies carried out by management. Therefore, the performance of the board of commissioners will be better with better coordination and alignment with the interests of shareholders (Lipton and Lorsch, 1992). Research conducted by Fathurrohman (2016) shows that the number of board of commissioners has a negative and significant effect on the capital structure proxied by the debt-toequity ratio.

Arping et al. (2009) in his research found that improving corporate governance significantly reduces the value of debt as a disciplinary tool. This result contradicts the findings of a study conducted by Daud et al. (2011) who found that good corporate governance practices have a positive and significant effect on external funding.

The research conducted by Al-Najjar et al. (2007) found that governance has a positive and significant effect on ownership cash. Based on this explanation, the hypotheses built in this study are;

H3 : Good Corporate Governance has a positive and significant effect on Internal Funding

\section{The Effect of Corporate Governance on Investment Efficiency}

According to Meisser et al. (2006) agency relationships lead to two problems, namely the occurrence of information asymmetry and conflicts of interest. Information asymmetry occurs where management generally has more information about the actual financial position and operating position of the entity than owners. Meanwhile, conflicts of interest occur due to unequal goals, where management does not always act in accordance with the interests of the owner.

Based on the model developed by Jensen and Meckling (1976) information asymmetry creates moral hazard and adverse selection that can affect the efficiency of investments made by the company. In terms of moral hazard, differences in interests among shareholders and the lack of a monitoring process from managers will encourage management to maximize their 
interests through investment activities that can harm the interests of shareholders. So this will lead to overinvestment (Hope and Thomas, 2008). Meanwhile, adverse selection occurs when the perception of the owner of the capital on the company's performance is different from the actual situation. Companies that implement good governance

A good investment makes companies able to make appropriate and efficient investments (Houcine, 2013). From several previous studies, such as Houcine (2013), Zheka (2003), and Saleh et al. (2009) found several factors that can influence companies to be able to invest efficiently is corporate governance. Research conducted by Chen et al. (2017) found different results, namely that governance has a negative effect on investment efficiency, and this effect is more pronounced in SOEs than in private companies. While Salin et al. (2018) in his research found that governance has a negative and significant effect on investment efficiency. Research conducted by Qian et al. (2014) show that governance and investment efficiency have a positive effect. Based on this explanation, the hypotheses built in this study are;

H4 : Corporate governance has a positive and significant effect on investment efficiency

\section{The Effect of Internal Funding on Investment Efficiency}

The importance of internal financing in corporate investment and financing decision making has been widely studied (Hall, 2002; Hubbard, 1998). The Pecking Order Theory proposed by Myers (1984) shows that internal financing reduces information asymmetry, avoids the risk of adverse selection from external financing and reduces conflicts between corporate stakeholders.

When the company's internal funding is abundant, excess free cash flow is generated, so the company can take advantage of the excess internal funds for investment. However, due to moral hazard, excess free cash flow can also cause overinvestment, in line with the theory of overinvestment free cash flow, when managers, as company agents, have excess cash on hand, they can pursue personal interests and expand the scale of investment using the funds received. This allows managers to increase their income, status and power and build their own 'business empire'. Renneboog et. al (2007) proposed that there are 2 types of errors in the company. The first or type I error is overinvesting when the cash flow is sufficient. Second, or type II error, namely underinvesting with a lack of cash flow. An increase in internal funding will increase the occurrence of Type I errors but reduce Type II errors. A reduction in internal funding will result in a shortage of free cash flow so that cash flow cannot meet the company's investment needs. Even if there is an investment opportunity or project with a positive NPV, the company will make insufficient investment.

He et al. (2019) in his research found that internal funding has a positive impact on investment efficiency. However, in contrast to the findings of Grosman's (2012) research, it shows that cash flow does not have a significant effect on investment efficiency. Meanwhile, research conducted by Wang et al. (2015) and Jiang (2016); find that free cash flow can affect the efficiency of investment projects. Based on the description and previous research, this study proposes the following hypotheses: H5: Internal funding has a positive and significant effect on investment efficiency

\section{Internal Funding plays a role as mediating the influence of Managerial Overconfidence Investment Efficiency}

Managerial overconfidence not only has an impact on financial decisions but also investment efficiency (Malmendier and Tate, 2005). When managers are very overconfident, they have an optimistic attitude about the company's prospects and see an increase in investment as good news. Therefore, they increase the level of investment by increasing internal funding and have an impact on increasing the company's performance in order to obtain personal benefits. They may mistakenly think that projects with negative NPV are positive NPV. Furthermore, junior managers who wish to quickly build their reputation for attracting investors are more likely than senior managers to improve short-term performance by making the firm invest in inefficient (Baker and Wurgler, 2000).

Overconfident managers also believe that their company's shares are undervalued in the market, and tend to overestimate the likelihood of success so that it is easier to overinvest using the cash flows generated by internal funding futures and alleviate investment shortfalls caused by cash flow shortages. In short, internal funding plays a role transmission between managerial overconfidence and investment efficiency. Research conducted by $\mathrm{He}$ et al. (2019) found that increasing internal funding can fund business opportunities thereby expanding investment and alleviating underinvestment, and thereby having an impact on increasing investment efficiency, but can also lead to overinvestment, especially in companies with managerial overconfidence.

Mohamed et al. (2014); Liu, Mu, Wen (2016); and Moez, Amina (2017) in their research found that overconfident managers tend to affect the efficiency of investment projects with internal funding. In addition, Shima et al. (2018) found that managerial overconfidence has a positive and significant effect on increasing investment-cash flow sensitivity.

H6: Internal funding mediates the effect of managerial overconfidence on investment efficiency

\section{The Role of Internal Funding in Mediating the Effect of Corporate Governance on Investment Efficiency}

Pecking Order Theory according to Myers \& Majluf (1984) explains the hierarchy of the company's funding sources, namely internal sources of funds, debt and the issuance of shares. Funding decisions are important things that need to be considered by managers when managing the company's funding 
structure from internal funding sources as well as funding sources external. The importance of internal financing in corporate investment and financing decision making has been widely studied (Halll, 2002; Hubbard, 1998).

According to Meisser et al., (2006) agency relationships lead to two problems, namely the occurrence of information asymmetry and conflicts of interest. Based on the model developed by Jensen and Meckling (1976) information asymmetry creates moral hazard and adverse selection that can affect the efficiency of investments made by the company.

The Pecking Order Theory proposed by Myers (1984) also shows that internal funding can reduce information asymmetry, avoid adverse selection risks from external financing and reduce conflicts between company stakeholders. When the company's internal funding is abundant, excess free cash flow is generated, so the company can take advantage of the excess internal funds for investment. However, due to moral hazard, excess free cash flow can also lead to overinvestment. A reduction in internal funding will result in a shortage of free cash flow so that cash flow cannot meet the company's investment needs. Based on the description and previous research, this study proposes the following hypotheses:

H7: Internal funding acts as a mediation of the influence of corporate governance on investment efficiency

\section{Research Methods}

The population in this study were all state-owned companies that went public and were listed on the Indonesia Stock Exchange during the 2014-2018 period. The sampling method used was purposive sampling method. Sources of data in this study are secondary data, namely data obtained from other parties who have collected it first. The data sources used consisted of:

1 Indonesia Stock Exchange (IDX), published in 2011 to 2018 .

2 Annual reports for all companies selected as sample members, from 2011 to 2018.

3 Sample company financial reports for the period 2011-2018.

4 Based on the time dimension and time sequence, this study is cross-sectional and time series or called panel data (pooled data), because in addition to taking samples of events at a certain time, they also take samples based on time sequences.
Tabel 2

\section{Sample Selection Process}

\begin{tabular}{clc}
\hline No & \multicolumn{1}{c}{ Company Name } & $\begin{array}{c}\text { Stock } \\
\text { code }\end{array}$ \\
\hline 1 & PT Adhi Karya Tbk. & ADHI \\
2 & PT Aneka Tambang Tbk & ANTM \\
3 & PT Garuda Indonesia Tbk. & GIAA \\
4 & PT Indofarma Tbk & INAF \\
5 & PT Jasa Marga Tbk. & JSMR \\
6 & PT Kimia Farma Tbk. & KAEF \\
7 & PT Krakatau Steel Tbk. & KRAS \\
8 & PT Perusahaan Gas Negara Tbk. & PGAS \\
9 & PT Tambang Batubara Bukit Asam & PTBA \\
& Tbk. & \\
10 & PT Pembangunan Perumahan Tbk. & PTPP \\
\hline
\end{tabular}

Source: Researcher Elaboration, 2020

The data analysis method used to test the model in this study is a quantitative method. In this study, the data were analyzed through computer programs, namely Microsoft Excel and Eviews 9 using panel data regression tools. Panel data is a combination of time series and cross section data.

The panel data regression equation model in this study is as follows:

$$
\begin{aligned}
& Z=b_{0}+b_{1} X_{t-1}+b_{2} X_{t-1}+b_{3} X_{t-1}+b_{4} X_{t-1}+b_{5} X_{t-1}+b_{6} X_{t-1}+b_{7} X^{-1}+b_{8} X_{t-1}+e
\end{aligned}
$$

$\mathrm{Y}=\mathrm{b}_{0}+\mathrm{b}_{1} \mathrm{X}_{\mathrm{t}-1}+\mathrm{b}_{2} \mathrm{X}_{\mathrm{t}-1}+\mathrm{b}_{3} \mathrm{X}_{\mathrm{t}-1}+\mathrm{b}_{4} \mathrm{X}_{\mathrm{t}-1}+\mathrm{b}_{5} \mathrm{X}_{\mathrm{t}-1}+\mathrm{b}_{6} \mathrm{X}_{\mathrm{t}-1}+\mathrm{b}_{7} \mathrm{X}$ ${ }_{t-1}+b_{8} X_{t-1}+b_{9} Z_{t-1}+e$

Information :

$\mathrm{Y} \quad=$ Investment Efficiency

a $=$ Constant

b1-b8 = Regression Coefficient

$\mathrm{X} 1=$ Managerial Overconfidence

$\mathrm{X} 2=$ Firm Size

$\mathrm{X} 3=$ Financial Leverage

$\mathrm{X} 4=$ Investment Opportunity Set

X5 = Operating Results

$\mathrm{X} 6=$ Profitability

$\mathrm{X} 7=$ Cash Holdngs

$\mathrm{X} 8=$ Corporate Governance

$\mathrm{Z}^{\prime} \quad=$ Internal Financing

e $\quad=$ Error

\section{Results and Discussion}

\section{Estimation Model Determination}

Panel data regression can be done in three models, namely common effect, fixed effect and random effect. Each model has its advantages and disadvantages. The choice of model depends on the 
assumptions used by the researcher and the fulfillment of statistical data processing requirements that are correct so that it can be justified statistically. Therefore, the first step to take is to test the three available models.

\section{Common Effect Model}

CEM is a simple panel data model approach because it only combines time series and cross section data. In this model, neither the time dimension nor the individual is considered, so it is assumed that the data behavior is the same in various time periods. Based on the results of processing Eviews 9 using the common effect model for model I and model II.

\section{Tabel 3}

\section{Common Effect Model I}

Dependent Variable: Z

Method: Panel Least Squares

Sample: 20112018

Periods included: 8

Cross-sections included: 10

Total panel (balanced) observations: 80

\begin{tabular}{crrrr}
\hline \hline Variable & Coefficient Std. Error & t-Statistic & Prob. \\
\hline C & -0.597443 & 0.009692 & -61.64123 & 0.0000 \\
X1 & 0.015589 & 0.000522 & 29.84393 & 0.0000 \\
X2 & 0.024411 & 0.001502 & 16.25249 & 0.0000 \\
X3 & 0.027242 & 0.002277 & 11.96436 & 0.0000 \\
X4 & 0.024880 & 0.000162 & 153.1287 & 0.0000 \\
X5 & 0.050292 & 0.011672 & 4.308820 & 0.0001 \\
X6 & 0.025444 & 0.005768 & 4.411001 & 0.0000 \\
X7 & 0.027828 & 0.003788 & 7.346573 & 0.0000 \\
X8 & -0.000411 & 0.002014 & -0.203990 & 0.8389 \\
& & & & \\
\hline \hline & & & & \\
R-squared & 0.997939 & Mean dependent var & 0.213362 \\
Adjusted R-squared & 0.997707 & S.D. dependent var & 0.061752 \\
S.E. of regression & 0.002957 & Akaike info criterion & -8.703706 \\
Sum squared resid & 0.000621 & Schwarz criterion & -8.435728 \\
Log likelihood & 357.1482 & Hannan-Quinn criter. & -8.596266 \\
F-statistic & 4298.116 & Durbin-Watson stat & 1.025887 \\
Prob(F-statistic) & 0.000000 & & & \\
\hline \hline
\end{tabular}

Source: Processed Results Eviews 9, 2020

The results of the output of Eviews 9 in table 3 show that the managerial overconfidence, firm size, financial leverage, investment opportunity set, operating results, profitability and cash holdings variables are significant because more smaller than the significance level value that is 0.05 . Meanwhile, the corporate governance variable is not significant because it is greater than the significance level of 0.05 .
Based on the results of the Eviews 9 output in table 4 , it shows that the variable managerial overconfidence, firm size, financial leverage, investment opportunity set, operating results, profitability and cash holdings variables are significant because they are smaller than the significance level of 0.05 . Meanwhile, the variables of corporate governance and Internal Financing are not significant because they are greater than the significance level of 0.05 .

\section{Tabel 4}

\section{Common Effect Model II}

Dependent Variable: Z

Method: Panel Least Squares

Sample: 20112018

Periods included: 8

Cross-sections included: 10

Total panel (balanced) observations: 80

\begin{tabular}{crrrr}
\hline \hline Variable & Coefficient & Std. Error & t-Statistic & Prob. \\
\hline \hline C & -3.466240 & 0.024783 & -139.8649 & 0.0000 \\
X1 & -0.055716 & 0.000666 & -83.68683 & 0.0000 \\
X2 & 0.431551 & 0.001130 & 381.8747 & 0.0000 \\
X3 & -0.317102 & 0.001369 & -231.5610 & 0.0000 \\
X4 & 0.030839 & 0.001024 & 30.11413 & 0.0000 \\
X5 & 3.116724 & 0.004540 & 686.5170 & 0.0000 \\
X6 & -1.522122 & 0.002255 & -675.0705 & 0.0000 \\
X7 & -0.388024 & 0.001740 & -222.9577 & 0.0000 \\
X8 & $-9.60 \mathrm{E}-05$ & 0.000698 & -0.137544 & 0.8910 \\
Z & -0.033287 & 0.041099 & -0.809925 & 0.4207 \\
\hline \hline & 0.999975 & Mean dependent var & 0.533600 \\
R-squared & 0.999971 & S.D. dependent var & 0.191210 \\
Adjusted R-squared & 0.001024 & Akaike info criterion & -10.81374 \\
S.E. of regression & $7.34 \mathrm{E}-05$ & Schwarz criterion & -10.51599 \\
Sum squared resid & 442.5498 & Hannan-Quinn criter. & -10.69437 \\
Log likelihood & 306056.8 & Durbin-Watson stat & 2.526564 \\
F-statistic & 0.000000 & & & \\
Prob(F-statistic) & & & & \\
\hline \hline
\end{tabular}

Source: Processed Results Eviews 9,2020

\section{Fixed Effect Model}

The fixed effect model approach assumes that each individual is different while the slope between individuals is fixed (the same). Based on the results of processing Eviews 9 using fixed effects models for model I and model II. The results of the output of Eviews 9 in table 5 show that the managerial overconfidence, firm size, financial leverage, investment opportunity set, operating results, profitability and cash holdings variables are significant because they are smaller. from the significance level value that is 0.05 . Meanwhile, the 
corporate governance variable is not significant because it is greater than the significance level of 0.05 .

\section{Tabel 5}

\section{Fixed Effect Model I}

Dependent Variable: Z

Method: Panel Least Squares

Sample: 20112018

Periods included: 8

Cross-sections included: 10

Total panel (balanced) observations: 80

\begin{tabular}{|c|c|c|c|c|}
\hline \multicolumn{5}{|c|}{ Coefficien } \\
\hline Variable & $\mathrm{t}$ & Std. Error & $\mathrm{t}$-Statistic & Prob. \\
\hline $\mathrm{C}$ & -0.542880 & 0.019791 & -27.43113 & 0.0000 \\
\hline $\mathrm{X} 1$ & 0.015311 & 0.000633 & 24.20423 & 0.0000 \\
\hline $\mathrm{X} 2$ & 0.021067 & 0.001768 & 11.91504 & 0.0000 \\
\hline $\mathrm{X} 3$ & 0.024381 & 0.002330 & 10.46208 & 0.0000 \\
\hline $\mathrm{X} 4$ & 0.024664 & 0.000155 & 158.7433 & 0.0000 \\
\hline $\mathrm{X} 5$ & 0.055631 & 0.012704 & 4.378868 & 0.0000 \\
\hline $\mathrm{X} 6$ & 0.020615 & 0.006819 & 3.023181 & 0.0036 \\
\hline $\mathrm{X} 7$ & 0.026780 & 0.003901 & 6.864486 & 0.0000 \\
\hline $\mathrm{X} 8$ & -0.001616 & 0.002077 & -0.777778 & 0.4397 \\
\hline \multicolumn{5}{|c|}{ Effects Specification } \\
\hline \multicolumn{5}{|c|}{ Cross-section fixed (dummy variables) } \\
\hline R-squared & 0.998737 & \multicolumn{2}{|c|}{ Mean dependent var } & 0.213362 \\
\hline Adjusted R-squared & 0.998390 & \multicolumn{2}{|c|}{ S.D. dependent var } & 0.061752 \\
\hline S.E. of regression & 0.002478 & \multicolumn{2}{|c|}{ Akaike info criterion } & -8.967914 \\
\hline Sum squared resid & 0.000381 & \multicolumn{2}{|c|}{ Schwarz criterion } & -8.431958 \\
\hline Log likelihood & 376.7166 & \multicolumn{2}{|c|}{ Hannan-Quinn criter. } & -8.753034 \\
\hline F-statistic & 2883.101 & \multicolumn{2}{|c|}{ Durbin-Watson stat } & 1.375484 \\
\hline Prob(F-statistic) & 0.000000 & & & \\
\hline
\end{tabular}

Source: Processed Results Eviews 9,2020

Based on the results of the Eviews 9 output in table 6 , it shows that the variable managerial overconfidence, firm size, financial leverage, investment opportunity set, operating results, profitability and cash holdings variables are significant because they are smaller than the significance level of 0.05 . Meanwhile, the variables of corporate governance and Internal Financing are not significant because they are greater than the significance level of 0.05 .

\section{Tabel 6}

\section{Fixed Effect Model II}

Dependent Variable: Z

Method: Panel Least Squares

Sample: 20112018

Periods included: 8

Cross-sections included: 10

Total panel (balanced) observations: 80

\begin{tabular}{|c|c|c|c|c|}
\hline Variable & Coefficient & Std. Error & t-Statistic & Prob. \\
\hline $\mathrm{C}$ & -3.456534 & 0.030539 & -113.1828 & 0.0000 \\
\hline $\mathrm{X} 1$ & -0.056183 & 0.000871 & -64.53596 & 0.0000 \\
\hline $\mathrm{X} 2$ & 0.431705 & 0.001365 & 316.1838 & 0.0000 \\
\hline $\mathrm{X} 3$ & -0.317325 & 0.001650 & -192.3229 & 0.0000 \\
\hline $\mathrm{X} 4$ & 0.030707 & 0.001335 & 22.99764 & 0.0000 \\
\hline $\mathrm{X} 5$ & 3.118684 & 0.006189 & 503.8963 & 0.0000 \\
\hline X6 & -1.524407 & 0.003110 & -490.1768 & 0.0000 \\
\hline $\mathrm{X} 7$ & -0.388901 & 0.002204 & -176.4908 & 0.0000 \\
\hline $\mathrm{X} 8$ & $-1.35 \mathrm{E}-05$ & 0.000889 & -0.015234 & 0.9879 \\
\hline Z & -0.026148 & 0.054071 & -0.483597 & 0.6304 \\
\hline \multicolumn{5}{|c|}{ Effects Specification } \\
\hline \multicolumn{5}{|c|}{ Cross-section fixed (dummy variables) } \\
\hline R-squared & 0.999976 & \multicolumn{2}{|c|}{ Mean dependent var } & 0.533600 \\
\hline Adjusted R-squared & 0.999970 & \multicolumn{2}{|c|}{ S.D. dependent var } & 0.191210 \\
\hline S.E. of regression & 0.001055 & \multicolumn{2}{|c|}{ Akaike info criterion } & -10.66696 \\
\hline Sum squared resid & $6.79 \mathrm{E}-05$ & \multicolumn{2}{|c|}{ Schwarz criterion } & -10.10123 \\
\hline Log likelihood & 445.6784 & \multicolumn{2}{|c|}{ Hannan-Quinn criter. } & -10.44014 \\
\hline F-statistic & 144202.6 & \multicolumn{2}{|c|}{ Durbin-Watson stat } & 2.658176 \\
\hline Prob(F-statistic) & 0.000000 & & & \\
\hline
\end{tabular}

Source: Processed Results Eviews 9,2020

\section{Random Effect Model}

REM is a model that estimates panel data where the disturbance variables may be interrelated over time and between individuals. Based on the results of processing Eviews 9 using fixed effects models for model I and model II.

\section{Tabel 7}

\section{Random Effect Model I}

Dependent Variable: Z

Method: Panel EGLS (Cross-section random effects)

Sample: 20112018

Periods included: 8

Cross-sections included: 10

Total panel (balanced) observations: 80

Swamy and Arora estimator of component variances

\begin{tabular}{|c|c|c|c|c|}
\hline Variable & Coefficien & Std. Error & t-Statistic & Prob \\
\hline $\mathrm{C}$ & -0.597443 & 0.008121 & -73.56449 & 0.0000 \\
\hline $\mathrm{X} 1$ & 0.015589 & 0.000438 & 35.61664 & 0.0000 \\
\hline $\mathrm{X} 2$ & 0.024411 & 0.001259 & 19.39621 & 0.0000 \\
\hline X3 & 0.027242 & 0.001908 & 14.27862 & 0.0000 \\
\hline $\mathrm{X} 4$ & 0.024880 & 0.000136 & 182.7484 & 0.0000 \\
\hline $\mathrm{X} 5$ & 0.050292 & 0.009780 & 5.142275 & 0.0000 \\
\hline X6 & 0.025444 & 0.004833 & 5.264221 & 0.0000 \\
\hline \multirow[t]{4}{*}{$\mathrm{X} 7$} & 0.027828 & 0.003174 & 8.767620 & 0.0000 \\
\hline & -0.000411 & 0.001687 & -0.243448 & 0.8084 \\
\hline & \multicolumn{4}{|c|}{ Effects Specification } \\
\hline & & & S.D. & Rho \\
\hline
\end{tabular}




\begin{tabular}{llll}
$\begin{array}{l}\text { Cross-section random } \\
\text { Idiosyncratic random }\end{array}$ & 0.000000 & 0.0000 \\
& Weighted Statistics & 0.002478 & 1.0000 \\
\hline \hline $\begin{array}{l}\text { R-squared } \\
\text { Adjusted R- } \\
\text { squared }\end{array}$ & 0.997939 & Mean dependent var & 0.213362 \\
$\begin{array}{l}\text { S.E. of } \\
\text { regression }\end{array}$ & 0.997707 & S.D. dependent var & 0.061752 \\
$\begin{array}{l}\text { F-statistic } \\
\text { Prob(F- } \\
\text { statistic) }\end{array}$ & 4298.116 & Durbin-Watson stat & 0.000621 \\
\hline \hline & 0.000000 & & 1.025887 \\
\hline \hline $\begin{array}{l}\text { R-squared } \\
\text { resid }\end{array}$ & 0.997939 & Mean dependent var & 1.025887 \\
\hline \hline
\end{tabular}

Source: Processed Results Eviews 9,2020

The results of Eviews 9 in table 7 show that the managerial overconfidence, firm size, financial leverage, investment opportunity set, operating results, profitability and cash holdings variables are significant. because it is smaller than the significance level of 0.05 . Meanwhile, the corporate governance variable is not significant because it is greater than the significance level of 0.05 .

\section{Tabel 8}

\section{Random Effect Model II}

Dependent Variable: Z

Method: Panel EGLS (Cross-section random effects)

Sample: 20112018

Periods included: 8

Cross-sections included: 10

Total panel (balanced) observations: 80

Swamy and Arora estimator of component variances

\begin{tabular}{|c|c|c|c|c|}
\hline Variable & Coefficient & Std. Error & t-Statistic & Prob. \\
\hline $\mathrm{C}$ & -3.466240 & 0.025530 & -135.7716 & 0.0000 \\
\hline $\mathrm{X} 1$ & -0.055716 & 0.000686 & -81.23764 & 0.0000 \\
\hline $\mathrm{X} 2$ & 0.431551 & 0.001164 & 370.6987 & 0.0000 \\
\hline $\mathrm{X} 3$ & -0.317102 & 0.001411 & -224.7841 & 0.0000 \\
\hline $\mathrm{X} 4$ & 0.030839 & 0.001055 & 29.23280 & 0.0000 \\
\hline $\mathrm{X} 5$ & 3.116724 & 0.004677 & 666.4252 & 0.0000 \\
\hline X6 & -1.522122 & 0.002323 & -655.3138 & 0.0000 \\
\hline $\mathrm{X} 7$ & -0.388024 & 0.001793 & -216.4325 & 0.0000 \\
\hline $\mathrm{X} 8$ & $-9.60 \mathrm{E}-05$ & 0.000719 & -0.133518 & 0.8942 \\
\hline $\mathrm{Z}$ & -0.033287 & 0.042338 & -0.786221 & 0.4344 \\
\hline \multicolumn{5}{|c|}{ Effects Specification } \\
\hline & & & S.D. & Rho \\
\hline Cross-section random & & & 0.000000 & 0.0000 \\
\hline Idiosyncratic random & & & 0.001055 & 1.0000 \\
\hline
\end{tabular}

Weighted Statistics

\begin{tabular}{llll}
\hline \hline R-squared & 0.999975 & Mean dependent var & 0.533600 \\
Adjusted R-squared & 0.999971 & S.D. dependent var & 0.191210 \\
S.E. of regression & 0.001024 & Sum squared resid & $7.34 \mathrm{E}-05$ \\
F-statistic & 306056.8 & Durbin-Watson stat & 2.526564 \\
Prob(F-statistic) & 0.000000 & & \\
\hline \hline & Unweighted Statistics & \\
\hline \hline & & & \\
R-squared & 0.999975 & Mean dependent var & 0.533600 \\
Sum squared resid & $7.34 \mathrm{E}-05$ & Durbin-Watson stat & 2.526564 \\
\hline \hline
\end{tabular}

Source: Processed Results Eviews 9,2020

The results of the Eviews 9 output in table 8 it shows that the variable managerial overconfidence, firm size, financial leverage, investment opportunity set, operating results, profitability and cash holdings variables are significant because they are smaller than the significance level of 0.05 . Meanwhile, the variables of corporate governance and Internal Financing are not significant because they are greater than the significance level of 0.05 .

\section{Model Selection (Estimation Technique) Panel Data Regression}

\section{Chow test}

The Chow test is a test to determine whether the Common Effect (CE) or Fixed Effect (FE) model is the most appropriate to be used in estimating panel data. The Chow test is carried out with the following hypothesis:

$\mathrm{H}_{0}$ : Common Effect Model

$\mathrm{H}_{1}$ : Fixed Effect Model

The decision making rule is if the probability for cross section $\mathrm{F}<0.05$ then $\mathrm{H}_{0}$ is rejected and $\mathrm{H}_{1}$ is accepted so that the correct model is the fixed effect model. Conversely, if the probability for cross section $\mathrm{F}>0.05$ then $\mathrm{H}_{0}$ is accepted and $\mathrm{H}_{1}$ is rejected so that the right model is a commont effect model.

\section{Tabel 9}

\section{Chow Test Model I}

Redundant Fixed Effects Tests

Equation: Untitled

Test cross-section fixed effects

\begin{tabular}{lrrr}
\hline \hline Effects Test & Statistic & d.f. & Prob. \\
\hline \hline Cross-section F & 4.347059 & $(9,62)$ & 0.0002 \\
Cross-section Chi-square & 39.136675 & 9 & 0.0000
\end{tabular}

Source: Processed Results Eviews 9,2020

Models the probability value (Prob) for the cross section $\mathrm{F}$ of 0.0002 for a value $<0.05$ (defined as the 
initial significance level or alpha). So it can be concluded that the fixed effect (FE) is more appropriate to use for model I than the common effect $(\mathrm{CE})$ value. $\mathrm{H}_{0}$ is rejected and $\mathrm{H}_{1}$ is accepted.

\section{Tabel 10}

\section{Chow Test Model II}

Redundant Fixed Effects Tests

Equation: Untitled

Test cross-section fixed effects

\begin{tabular}{lrrr}
\hline \hline Effects Test & Statistic & d.f. & Prob. \\
\hline \hline Cross-section F & 0.551410 & $(9,61)$ & 0.8309 \\
Cross-section Chi-square & 6.257230 & 9 & 0.7139
\end{tabular}

Source: Processed Results Eviews 9,2020

Model II the probability value (Prob) for the cross section $\mathrm{F}$ of 0.8309 for a value $>0.05$ (defined at baseline as a significance level or alpha). So it can be concluded that the common effect (CE) is more appropriate for model II than the fixed effect (FE) value. $\mathrm{H}_{0}$ is accepted and $\mathrm{H}_{1}$ is rejected.

\section{Hausman Test}

The Hausman test is conducted to compare or choose which model is the best between the fixed effect model (FE) and the random effect model (RE). The Hausman test is carried out with the following hypothesis:

$\mathrm{H}_{0}$ : Random Effect Model

$\mathrm{H}_{1}$ : Fixed Effect Model

The Hausman test statistical model follows the ChiSquare statistical distribution with a degree of freedom $<0.05$, then $\mathrm{H}_{0}$ is rejected and $\mathrm{H}_{1}$ is accepted so that the correct model is the fixed effect model. Conversely, if the probability for cross section $\mathrm{F}>0.05$ then $\mathrm{H}_{0}$ is accepted and $\mathrm{H}_{1}$ is rejected, so the correct model is the random effects model.Based on the results of processing Eviews 9 using the Hausman test for model I and model II.

\section{Tabel 11}

\section{Hausman Test Model I}

Correlated Random Effects - Hausman Test

Equation: Untitled

Test cross-section random effects

\begin{tabular}{|c|c|c|c|}
\hline Test Summary & Chi-Sq. Statistic & Chi-Sq. d.f. & Prob. \\
\hline Cross-section random & 38.785654 & & 0.0000 \\
\hline
\end{tabular}

Source: Processed Results Eviews 9,2020

Model I, the estimation results of the Hausman test, the random cross section probability value is 0.0000 $<0.05$, it can be concluded that the most appropriate model for model I is by using a fixed effect model.

\section{Tabel 11}

\section{Hausman Test Model II}

Correlated Random Effects - Hausman Test

Equation: Untitled

Test cross-section random effects

\begin{tabular}{lrrr}
\hline \hline Test Summary & Chi-Sq. Statistic & Chi-Sq. d.f. & Prob. \\
\hline \hline Cross-section random & 4.962687 & 90.8375
\end{tabular}

Source: Processed Results Eviews 9,2020

Model II estimation results of the Hausman test, the random cross section probability value is $0.8375>0.05$, it can be concluded that the most appropriate model for model II is to use the random effect model.

\section{Lagrange Multiplier (LM) test}

The final step in the model selection test is to perform the Lagrange Multiplier test which tests the Common Effect and Random Effect (Ali, 2016). The LM test hypothesis is:

$\mathrm{H}_{0}$ : Common Effect Model

$\mathrm{H}_{1}$ : Random Effect Model

The estimation results of the lagrange multiplier (LM) test show that the calculated LM value is $0.0720>0.05$, meaning that the calculated LM value $>$ chi-squared table.

\section{Tabel 12}

\section{Langrange Test Model II}

Lagrange multiplier (LM) test for panel data

Sample: 20112018

Total panel observations: 80

Probability in ()

\begin{tabular}{lccc}
\hline \hline $\begin{array}{l}\text { Null (no rand. effect) } \\
\text { Alternative }\end{array}$ & $\begin{array}{c}\text { Cross-section } \\
\text { One-sided }\end{array}$ & $\begin{array}{c}\text { Period } \\
\text { One-sided }\end{array}$ & Both \\
\hline \hline Breusch-Pagan & 3.237361 & 0.037089 & 3.274450 \\
& $(0.0720)$ & $(0.8473)$ & $(0.0704)$ \\
Honda & -1.799267 & -0.192585 & -1.408452 \\
& $(0.9640)$ & $(0.5764)$ & $(0.9205)$ \\
King-Wu & -1.799267 & -0.192585 & -1.334542 \\
& $(0.9640)$ & $(0.5764)$ & $(0.9090)$ \\
SLM & -1.260142 & 0.048282 & -- \\
& $(0.8962)$ & $(0.4807)$ & -- \\
GHM & -- & - & 0.000000 \\
& -- & - & $(0.7500)$ \\
\hline \hline
\end{tabular}

Source: Processed Results Eviews 9,2020

Model II the conclusions are consistently obtained from the results lagrange multiplier which determines that the appropriate model used for this research is random effect model (BRAKE). 


\section{Hypothesis test}

\section{$t$ Test (Partial Test)}

The $t$ statistical test is used to measure how far the influence of each independent variable is in explaining the dependent variable. In this model the t-table value is obtained using the provisions of the $\alpha$ (alpha) value of 0.05 and the degree of freedom value of 70 , then the $t-$ table of 1.99. The results of the F test can be seen in the following table:

\section{Tabel 13}

\section{Partial Test Results of Model I}

Dependent Variable: Z

Method: Panel Least Squares

Sample: 20112018

Periods included: 8

Cross-sections included: 10

Total panel (balanced) observations: 80

\begin{tabular}{crrrr}
\hline \hline Variable & Coefficient & Std. Error & t-Statistic & Prob. \\
\hline \hline C & -0.542880 & 0.019791 & -27.43113 & 0.0000 \\
X1 & 0.015311 & 0.000633 & 24.20423 & 0.0000 \\
X2 & 0.021067 & 0.001768 & 11.91504 & 0.0000 \\
X3 & 0.024381 & 0.002330 & 10.46208 & 0.0000 \\
X4 & 0.024664 & 0.000155 & 158.7433 & 0.0000 \\
X5 & 0.055631 & 0.012704 & 4.378868 & 0.0000 \\
X6 & 0.020615 & 0.006819 & 3.023181 & 0.0036 \\
X7 & 0.026780 & 0.003901 & 6.864486 & 0.0000 \\
X8 & -0.001616 & 0.002077 & -0.777778 & 0.4397
\end{tabular}

Source: Processed Results Eviews 9,2020

Based on the results of the Eviews 9 output in table 13 shows that the values of the independent variable managerial overconfidence and the control variable firm size, financial leverage, investment opportunity set, operating results, profitability and cash holdings $>$ t-table 1.99 then these variables significantly influence. on the Internal Financing variable. The independent variable of corporate governance has a t-value of $-0.78<\mathrm{t}$-table 1.99 , so corporate governance does not have a significant effect on the Internal Financing variable and has an opposite relationship.

\section{Tabel 14}

\section{Partial Test Results of Model II}

Dependent Variable: Z

Method: Panel Least Squares

Sample: 20112018

Periods included: 8

Cross-sections included: 10

Total panel (balanced) observations: 80

\begin{tabular}{crrrr}
\hline \hline Variable & Coefficient & Std. Error & t-Statistic & Prob. \\
\hline \hline C & -3.466240 & 0.025530 & -135.7716 & 0.0000 \\
X1 & -0.055716 & 0.000686 & -81.23764 & 0.0000 \\
X2 & 0.431551 & 0.001164 & 370.6987 & 0.0000
\end{tabular}

$\begin{array}{lrrrr}\text { X3 } & -0.317102 & 0.001411 & -224.7841 & 0.0000 \\ \text { X4 } & 0.030839 & 0.001055 & 29.23280 & 0.0000 \\ \text { X5 } & 3.116724 & 0.004677 & 666.4252 & 0.0000 \\ \text { X6 } & -1.522122 & 0.002323 & -655.3138 & 0.0000 \\ \text { X7 } & -0.388024 & 0.001793 & -216.4325 & 0.0000 \\ \text { X8 } & -9.60 E-05 & 0.000719 & -0.133518 & 0.8942\end{array}$

Source: Processed Results Eviews 9,2020

Based on the results of the Eviews 9 output in table 14, it shows that the values of the independent variable managerial overconfidence and the control variables of financial leverage, profitability and cash holdings $>\mathrm{t}$-table 1.99 show that these variables significantly influence investment efficiency but have opposite relationships. For other control variables, namely firm size, investment opportunity set, operating results $>$ t-table 1.99 , this means that these variables significantly influence investment efficiency. While the independent variable corporate governance and the Internal Financing mediation variable have a t-value $<$ t-table 1.99 , so these variables do not significantly influence the investment efficiency variable and have an opposite relationship.

\section{F Test (Model Feasibility)}

According to Ghozali (2006), the F statistical test basically shows whether all the independent variables that are included in the model have a joint influence on the dependent variable. The results of the F test can be seen in the following table:

\section{Table 15}

\section{Simultaneous Test Results of Model I}

Effects Specification

\begin{tabular}{lrlr}
\hline \hline Cross-section fixed (dummy variables) & \\
\hline \hline R-squared & 0.998737 & Mean dependent var & 0.213362 \\
Adjusted R-squared & 0.998390 & S.D. dependent var & 0.061752 \\
S.E. of regression & 0.002478 & Akaike info criterion & -8.967914 \\
Sum squared resid & 0.000381 & Schwarz criterion & -8.431958 \\
Log likelihood & 376.7166 & Hannan-Quinn criter. & -8.753034 \\
F-statistic & 2883.101 & Durbin-Watson stat & 1.375484 \\
Prob(F-statistic) & 0.000000 & & \\
\hline
\end{tabular}

Source: Processed Results Eviews 9,2020

Based on table 15 , it can be seen that the probability $\mathrm{F}$ statistics for the fixed effect model on the Internal Financing variable is equal to 0.000000 . with an eligibility level of 5\% (alpha 0.05 ) so that with this value it can be seen that the probability value $\mathrm{F}<0.05$. This means that the independent variablemanagerial overconfidence and corporate governance as well as control variables firm size, financial leverage, investment opportunity set, operating results, profitability, cash holdingssimultaneously affect the variablesInternal Financing. 
Table 16

\section{Simultaneous Test Results of Model II}

Effects Specification

\begin{tabular}{|c|c|c|c|}
\hline \multirow{2}{*}{\multicolumn{4}{|c|}{ EIrects specirication }} \\
\hline & & S.D. & \\
\hline Cross-section random & & 0.000000 & 0.0000 \\
\hline Idiosyncratic random & & 0.001055 & 1.0000 \\
\hline \multicolumn{4}{|c|}{ Weighted Statistics } \\
\hline R-squared & 0.999975 & Mean dependent var & 0.533600 \\
\hline Adjusted R-squared & 0.999971 & S.D. dependent var & 0.191210 \\
\hline S.E. of regression & 0.001024 & Sum squared resid & $7.34 \mathrm{E}-05$ \\
\hline F-statistic & 306056.8 & Durbin-Watson stat & 2.526564 \\
\hline Prob(F-statistic) & 0.000000 & & \\
\hline
\end{tabular}

Source: Processed Results Eviews 9,2020

Based on table 16 it can be seen that the probability $\mathrm{F}$ statistic for the random effect model on the investment efficiency variable is equal to 0.000000 . with an eligibility level of $5 \%$ (alpha 0.05 ) so that with this value it can be seen that the probability value $F<0.05$. This means that the independent variable managerial overconfidence andcorporate governance and control variables firm size, financial leverage, investment opportunity set, operating results, profitability, cash holdings and Internal Financing mediation variablessimultaneously affect the investment efficiency variable.

\section{Coefficient of Determination $\left(R^{2}\right)$}

The coefficient of determination test is carried out to assess the influence of the independent variable on the dependent variable. The results of the F test can be seen in the following table:

\section{Table 17}

\section{Coefficient of Determination Test of Model I}

Effects Specification

\begin{tabular}{|c|c|c|c|}
\hline \multicolumn{4}{|l|}{ Cross-section fixed } \\
\hline R-squared & 0.998737 & Mean dependent var & 0.213362 \\
\hline $\begin{array}{l}\text { Adjusted R- } \\
\text { squared }\end{array}$ & 0.998390 & S.D. dependent var & 0.061752 \\
\hline S.E. of regression & 0.002478 & Akaike info criterion & -8.967914 \\
\hline Sum squared resid & 0.000381 & Schwarz criterion & -8.431958 \\
\hline Log likelihood & 376.7166 & Hannan-Quinn criter. & -8.753034 \\
\hline F-statistic & 2883.101 & Durbin-Watson stat & 1.375484 \\
\hline Prob(F-statistic) & 0.000000 & & \\
\hline
\end{tabular}

Source: Processed Results Eviews 9,2020

Determination test results Based on table 17 of the test results using the fixed effect model, the value of R2 reflects the large proportion of variations in the dependent variable $\mathrm{Y}$ which can be explained using the independent variable $X$. Equation model I shows a value of R2 of 0.998737 means that the variable Y (Internal Financing) can be explained by the regression model for $99.87 \%$ and the remaining $0.13 \%$ is explained by other factors outside the model used.

\section{Table 18}

\section{Coefficient of Determination Test of Model II \\ Effects Specification}

\begin{tabular}{lrc} 
& S.D. & Rho \\
\hline \hline Cross-section random & 0.000000 & 0.0000 \\
Idiosyncratic random & 0.001055 & 1.0000 \\
\hline \hline
\end{tabular}

Weighted Statistics

\begin{tabular}{llll}
\hline \hline R-squared & 0.999975 & Mean dependent var & 0.533600 \\
Adjusted R-squared & 0.999971 & S.D. dependent var & 0.191210 \\
S.E. of regression & 0.001024 & Sum squared resid & $7.34 \mathrm{E}-05$ \\
F-statistic & 306056.8 & Durbin-Watson stat & 2.526564 \\
Prob(F-statistic) & 0.000000 & & \\
\hline \hline
\end{tabular}

Unweighted Statistics

\begin{tabular}{llll}
\hline \hline R-squared & 0.999975 & Mean dependent var & 0.533600 \\
Sum squared resid & $7.34 \mathrm{E}-05$ & Durbin-Watson stat & 2.526564 \\
\hline
\end{tabular}

\section{Source: Processed Results Eviews 9,2020}

Based on table 18 of the test results using the random effect model, the value of $\mathrm{R} 2$ reflects the large proportion of variations in the dependent variable $\mathrm{Y}$ which can be explained using the independent variable $\mathrm{X}$. Equation model II shows a value of R2 of 0.999975 means that the variable Y (Investment Efficiency) can be explained by the regression model for $99.99 \%$ and the remaining $0.01 \%$ is explained by other factors outside the model used.

\section{Path Analysis Hypothesis Test}

Path analysis is an analysis technique used to study the causal relationship between independent and dependent variables. In this study, the relationship between the independent variables (managerial overconfidence and corporate governance) and the dependent variable (investment efficiency) is mediated by the intervening variable (Internal Financing).

Table 3

Summary of Path Coefficients

\begin{tabular}{|c|c|c|c|c|}
\hline Variable & Coeff & St.Error & t-count & Prob. \\
\hline $\begin{array}{l}\text { Managerial } \\
\text { Overconfidence - } \\
\text { Internal Financing }\end{array}$ & 0.0153 & 0.00063 & 24,2 & 0.00 \\
\hline $\begin{array}{l}\text { Good Corporate } \\
\text { Governance - Internal } \\
\text { Financing }\end{array}$ & -0.0016 & 0.00207 & -0.777778 & 0.43 \\
\hline $\begin{array}{l}\text { Managerial } \\
\text { Overconfidence - } \\
\text { Investment Efficiency }\end{array}$ & -0.0557 & 0.00068 & -81.23764 & 0.00 \\
\hline Good Corporate & $-9.60 \mathrm{E}-$ & 0.00071 & -0.133518 & 0.89 \\
\hline
\end{tabular}


Governance -

Investment Efficiency

$\begin{array}{lllll}\text { Internal Financing - } & -0.0332 & 0.04233 & -0.786221 & 0.43\end{array}$

Investment Efficiency

Source: Processed Eviews 9

Based on e1, which is the influence of other variables on Internal Financing, it can be calculated as e1= $\sqrt{(1-0.99)}=0.1$. The value of $\mathrm{e} 2$, which is the influence of other variables on investment efficiency, is calculated as e $2=\sqrt{(1-0.99 \mid}=0.1$. Based on the summary table of path coefficients and the calculation of e1 and e 2 above, the following structural equations are obtained:

Internal Financing $=0.015 \mathrm{X} 1+-0.002 \mathrm{X} 8+0.1$

InvestmentEfficiency $=-0.056 \mathrm{X} 1+-9.60 \mathrm{X} 8+-0.033 \mathrm{Z}+$ 0.1

Here is a path diagram of the structural equation above:

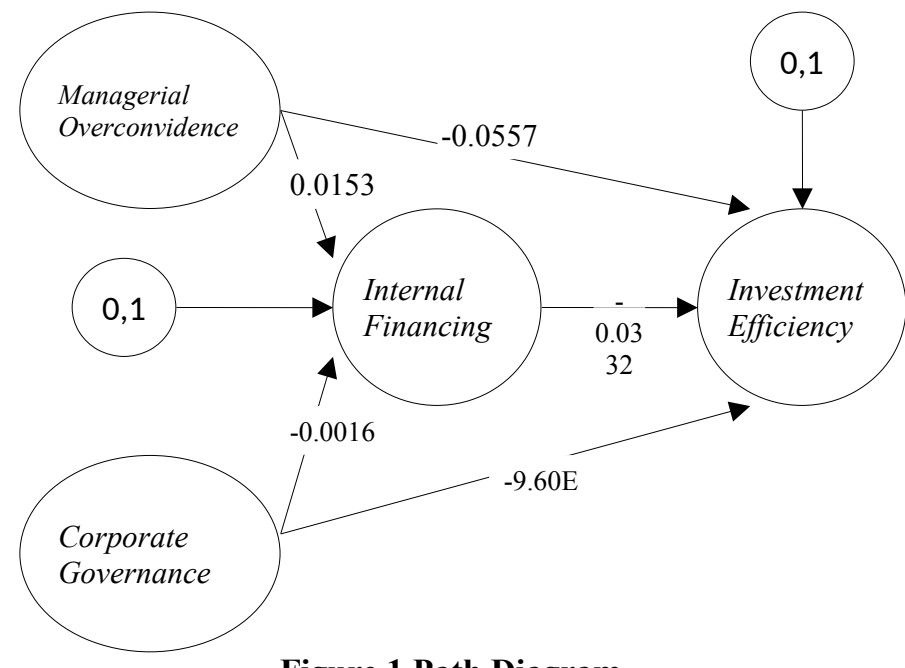

Figure 1 Path Diagram

From the summary table of the path coefficient above, it can be seen that managerial overconfidence has a significant negative effect on investment efficiency with a regression coefficient of -0.056 while the indirect effect of managerial overconfidence on investment efficiency through Internal Financing can be calculated as $0.015 \times-0.033=-0.000495$. And the total effect of managerial overconfidence on investment efficiency is $-0.056+-0.000495=0.056495$.

Corporate governance has a significant negative effect on investment efficiency with a regression coefficient of -9.60. Meanwhile, the indirect effect of corporate governance on investment efficiency through Internal Financing can be calculated as $-0.002 \mathrm{x}-0.033$ $=0.000066$. And the total effect of corporate governance on investment efficiency is $-9.60+-$ $0.000066=-9.59993$.

\section{Mediation Effect Detection Test}

In this study, there is a mediating variable (intervening) which is proxied by Internal Financing.
The sobel test is carried out by testing the strength of the indirect effect of managerial overconfidence and corporate governance on investment efficiency through the mediation variable of Internal Financing. Calculated by multiplying paths:

Managerial Overconfidence---Internal Financing $=0.015$ (a)

Internal Financing--------Investment Efficiency $=-0.033$ (b)

Corporate governance--------Internal Financing $=-0.002$ (c)

Internal Financing--------Investment Efficiency $=-0.033$ (d)

So the coefficient $a b=c d=\left(c-c^{\prime}\right)$, where $c$ is the effect of managerial overconfidence and corporate governance on investment efficiency without controlling Internal Financing, while $c^{\prime}$ is the coefficient of managerial overconfidence and corporate governance influence on investment efficiency after controlling for Internal Financing. . Standard error $a$ and $b$ are written with sa and $\mathrm{sb}$, standard error $\mathrm{c}$ and $\mathrm{d}$ are written with sc and sd. And the standard error for the indirect effect $a b$ is sab, cd is scd which is calculated by the formula:

a Path Calculation 1

Sat $=\sqrt{b^{2} s a^{2}+a^{2} s b^{2}+s a^{2} s b^{2}}$

Sat $=$

$\sqrt{(-0,033)^{2}(0,000633)^{2}+(0,015)^{2}(0,04)^{2}+(0,000633)^{2}(0,04)^{2}}$

Sat $=0.000601$

b Path Calculation 2

Sat $=\sqrt{d^{2} s c^{2}+c^{2} s d^{2}+s c^{2} s d^{2}}$

$\mathrm{Sat}=$

$\sqrt{(-0,033)^{2}(0,002)^{2}+(0,002)^{2}(0,04)^{2}+(0,002)^{2}(0,04)^{2}}$

Sat $=0.000131$

To test the significance of the indirect effect, we need to calculate the $t$ value of the coefficients $a b$ and $c d$ with the following formula:

a Line 1

b Line 2

$$
\mathrm{t}=-0.82363 \frac{a b}{s a b} \frac{0,015 \times(-0,033)}{0,000601}
$$

$$
\mathrm{t}=0.503817 \frac{c d}{s c d} \frac{(-0,002) x(-0,033)}{0,000131}
$$

From the calculation of the t-statistic value for line 1 and line 2 above, it can be seen that for line 1 the $t$ value of -0.82363 is smaller than the t-table with a significant level at 0.05 , namely 1.99 , it can be concluded that the mediation coefficient -0.82363 is not significant, which means there is no mediation effect.

For path 2 the t-count value of 0.503817 is smaller than the $\mathrm{t}$ table with a significant level of 0.05 , namely 1.99 , it can be concluded that the mediation coefficient of 0.9898 is not significant, which means there is no mediation effect. 


\section{Discussion}

\section{Effect of Managerial Overconfidence on Investment Efficiency}

Variable managerial overconfidencegives a negative coefficient estimation result. The t-test result shows that the variable managerial overconfidencehas a significant effect on investment efficiency in accordance with the initial hypothesis. Based on the results of the $t$ statistical test in table 14, it can be seen that managerial overconfidence has an influence on investment efficiency. This means high or low value managerial overconfidence a company is able to influence the value of investment efficiency. The results of this study state that managerial overconfidence has a negative and significant effect on investment efficiency.

The results of this study support the research conducted by Heaton (2002); Malmendier Tate (2005); and Xia et al. (2009) who found the same result that managerial overconfidence has a negative and significant effect on investment efficiency. Managers' choices for suboptimal levels of investment can stem from the CEO's overestimation of investment (Heaton, 2002 and Malmendier Tate, 2005). In line with the research conducted by $\mathrm{He}$ et al. (2019) found that managerial overconfidence causes overinvestment problems, especially in state-owned companies.

The results of this study indicate that managerial overconfidence has a negative and significant effect on investment efficiency. So that the first hypothesis proposed in this study is that managerial overconfidence has a negative and significant effect on investment efficiency.

\section{Effect of Managerial Overconfidence on Internal Financing}

Variable managerial overconfidenceprovides a positive coefficient estimation result. The t-test result shows that the variablemanagerial overconfidencehas a significant effect on investment efficiency in accordance with the initial hypothesis. Based on the results of the $t$ statistical test in table 13 it can be seen thatmanagerial overconfidence has an influence on Internal Financing. This means high or low value managerial overconfidence a company is able to influence the value of Internal Financing. The results of this study state that managerial overconfidence positive and significant effect on Internal Financing.

The results of this study support the research conducted by Huang et al. (2010) who found that agency costs had a positive and significant effect on the overconfidence of top executives on the use of cash flows. Managers with an optimism bias display a pecking-order preference (Malmendier et al., 2011).
According to the pecking order theory, companies tend to choose internal funding, then debt, and as a last resort to increase new equity (Myers, 1984). Managers with an overconfident bias are described as thinking that internal funding is the lowest cost of capital and can limit fluctuations from external borrowing markets and stock markets. In addition, managers with an overconfidence bias tend to have the illusion of control over technology and the accuracy of their own judgments. When making decisions, they tend to overestimate the likelihood of success that their company will show good profits and have great potential. So that through internal funding, overconfident managers have more control and believe that they can control the company's business performance.

The results of this study state that managerial overconfidence has a positive and significant effect on internal funding. So that the second hypothesis proposed in this study is that managerial overconfidence has a positive and significant effect on internal funding received.

\section{The Effect of Corporate Governance on Internal Financing}

The corporate governance variable gives a negative coefficient estimation result. The results of the t-test show that the corporate governance variable has an insignificant effect on Internal Financing. Based on the results of the $t$ statistical test in table 13 , it can be seen that corporate governance has no effect on Internal Financing. This means that the high or low value of corporate governance is not able to influence the value of Internal Financing. The results of this study state that corporate governancehas a negative and insignificant effect on Internal Financing.

The results of this study support the research conducted by Daud et al. (2011) who found that there was a negative and insignificant relationship between corporate governance and internal funding. Grossman (2012) states that companies that have increased additional debt should be subject to more supervision from banks and implement better governance rules to maximize the use of additional cash flows of investment projects. By not finding the effect of the board of commissioners relationship as measured by the number of board of commissioners meeting indicators on the company's internal funding, it can be indicated that companies will tend to practice better governance when they need to generate external funding.

The results of this study state that corporate governance has a negative and insignificant effect on internal funding. So that the third hypothesis proposed in this study is that corporate governance has a positive and significant effect on internal funding and is rejected. 


\section{Effect of Corporate Governance on Investment Efficiency}

The corporate governance variable gives a negative coefficient estimation result. The results of the t-test indicate that the corporate governance variable has an insignificant effect on investment efficiency. Based on the results of the $t$ statistical test in table 14, it can be seen that corporate governance has no effect on investment efficiency. This means that the high or low value of corporate governance is not able to affect the value of investment efficiency. The results of this study state that corporate governancehas a negative and insignificant effect on investment efficiency.

The results of this study support the research conducted by Chen et al. (2017) found that the number of meetings had a negative and insignificant effect on investment efficiency, and this effect was more pronounced in SOEs than in private companies. With no effect of the relationship of the board of commissioners being found as measured by the indicator of the number of board of commissioners' meetings on the level of efficiency of the company's investment, it can be indicated that the board of commissioners has not played an effective role in carrying out its functions. This is based on the fact that the duties and responsibilities of the board of commissioners are to provide control and advice to the company's management so that they can act in accordance with the existing principles of Good Corporate Governance. However, every company decision is determined by the company's board of directors. So that the board of commissioners does not have a direct influence on the decisions taken by the company, one of which is related to investment decisions, where these investment decisions can affect the level of efficiency of the company's investment.

The results of this study state that corporate governance has a negative and insignificant effect on investment efficiency. So that the fourth hypothesis proposed in this study is that corporate governance has a positive and significant effect on investment efficiency and is rejected.

\section{The Effect of Internal Financing on Investment Efficiency}

The Internal Financing variable gives a negative coefficient estimate. The results of the t-test indicate that the Internal Financing variable has no significant effect on investment efficiency. Based on the results of the $t$ statistical test in table 14, it can be seen that Internal Financing has no effect on investment efficiency. This means that the high or low value of the company's Internal Financing is not able to affect the value of investment efficiency. The results of this study state that
Internal Financinghas a negative and insignificant effect on investment efficiency.

The results of this study support the research conducted by Grossman (2012) showing that internal funding has no significant effect on investment efficiency. In setting investment policies, there are two types of funding sources that can be used by companies in financing their investment activities, namely internal funding and external funding. Internal funding comes from retained earnings $(\mathrm{R} / \mathrm{E})$ while external funding comes from stock issuance, bond issuance, and bank loans (Myers, Brealey \& Allen, 2006). However, in this study, internal funding sources realized in the form of retained earnings are not able to optimally fund the company's investment activities, so that the retained earnings generated by the company have a negative and insignificant effect on the level of efficiency of the company's investment.

The results of this study state that internal funding has a negative and insignificant effect on investment efficiency. So that the fifth hypothesis proposed in this study is that internal funding has a positive and significant effect on investment efficiency is rejected.

\section{Role Internal Financing as a mediation for the influence of Managerial Overconfidence on Investment Efficiency}

The magnitude of the role of Internal Financing as a mediation for the influence of managerial overconfidence on investment efficiency is calculated by multiplying the indirect coefficient, namely $0.015 \times-0.033=-0.0000495$. And the total effect of managerial overconfidence on investment efficiency is $-0.056+-0.000495=0.56495$. Based on the results of calculations with the Sobel test conducted in this study shows the standard error value of the indirect effect of 0.000601 for line 1 with a t-count value of -0.82363 smaller than the $t$-table with a significant level at 0.05 , namely 1.99 , it can be concluded that the coefficient mediation -0.82363 is not significant, which means that the role of Internal Financing as a mediation for the effect of managerial overconfidence on investment efficiency has a negative and insignificant effect on stateowned companies (BUMN) in the 2011-2018 period. So that the sixth hypothesis $\left(\mathrm{H}_{6}\right)$ proposed in this study is rejected.

\section{The role of Internal Financing in mediating the influence of Corporate Governance on Investment Efficiency}

The magnitude of the role of Internal Financing as a mediation for the influence of managerial overconfidence on investment efficiency is calculated by multiplying the indirect coefficient, namely $-0.002 \times-0.033=-0.000066$. And the total effect of managerial overconfidence on investment efficiency is $-9.60+-0.000066=-9.59993$. Based on the results of calculations with the single test 
carried out in this study, the standard error value of the indirect effect is 0.000131 for line 2 with a t-count value of 0.503817 smaller than the t-table with a significant level of 0.05 , namely 1,99 it can be concluded that the mediation coefficient is 0 , So that the seventh hypothesis $\left(\mathrm{H}_{7}\right)$ proposed in this study is rejected.

\section{Conclusion}

This study is conducted to examine empirically the factors that influence investment efficiency in State-Owned Enterprises (BUMN) on the Indonesia Stock Exchange. This study was tested with two independent variables are managerial overconfidence and corporate governance, intervening variable is internal financing. The results of this study found that investment efficiency in state-owned enterprises (BUMN) in Indonesia is largely determined by managerial overconfidence bias. Managers who have an overconfidence seek more aggressive and risky ventures so that they invest excessively beyond optimal levels. Managerial overconfidence in a manager can also strengthen the choice of internal financing, especially in state-owned companies. However, investment efficiency in this study is not influenced by corporate governance and internal financing. Corporate governance has also proven to have no role in corporate funding decisions. The role of internal financing as mediation was not found in this study. The results of this study are expected to be an illustration for the internal parties of the company, both management and company owners in minimizing the influence of overconfidence bias behavior which is sometimes not realized by company managers in making company decisions related to investment decisions, especially in state-owned companies (BUMN). In addition, good corporate governance practices need to be improved so that asymmetric information and agency problems that become the gap between agents and principals can be reducedreach the optimal level of investment.

The limitations that exist in this study, namely the measurement of managerial overconfidence using income forecast bias are deemed inaccurate because it only looks at the difference between forecast earnings which refers to time series, namely the effect of previous time and real profit, whereas in fact profit can also be influenced by internal factors and factors external. So there is a weakness in measuring overconfidence using secondary data based on forecasts. Apart from that, another limitation lies in the insufficient number of samples of stateowned companies (BUMN), so that it becomes an obstacle in determining the condition of investment efficiency of stateowned companies whether they experience overinvestment or underinvestment.

\section{References}

Boubaker, Sabri, Hamzah, Taher. 2014. Does Managerial overconfidence matter in explaining. Economics Bulletin, Vol 34 No. 4 pp. 2324-2339.

Brealey, Myers, and Marcus, 2011. Fundamentals of Corporate Financial Management. Jakarta: Erlangga.

Cooper, Donald R. and Defender S. Schindler. (2003). Business Research Methods, International Edition, McGraw-Hill Companies, Inc. New York.

David, Zainab. Qazi, Laila Taskeen. Atta-Ur-Rahman. 2011. Corporate Governance And External Finance: An Empirical Study Of The Banking And Financial Sector Of The Karachi Stock Exchange. Pakistan Business Review.

Eluyela, DF, Akintimehin, OO, Okere, W., Ozordi, E., Osuma, GO, Ilogho, SO, \& Oladipo, OA 2018. Board meeting frequency and firm performance: examining the nexus in Nigerian deposit money banks. Heliyon, 4 (10).

Gervais, S., Heaton, JB, Odean, T. 2002. The Positive Role of Overconfidence and Optimism in Investment Policy, Mimeo, University of California, Berkeley.

Goel, AM, Thakor, AV, 2008. Overconfidence, CEO selection, and corporate governance. J. Finance 63 (6), 2737-2784.

Griffin, W., Varey, Carol A. 1996.Towards a Consensus on Overconfidence. Elsevier. 65 (3), 227-231.

Grosman, Anna. 2012. Governance as a mechanism to alleviate financing constraints on investment. DRUID Academy.

Hackbarth, D., 2003. Managerial traits and capital structure decisions. J. Financ. Quant. Anal. 43 (4), 843-881.

He, Ying, Chen, Cindy and Hu, Yue. 2018.

Managerial overconfidence, internal financing, and investment efficiency: Evidence from China (Study of companies listed on the Shanghai and Shenzhen Stock Exchanges in 2010-2015) Research in International Business and Finance, 47 (2019), 501-510.

Heaton, JB 2002. Managerial Optimism And Corporate Finance. Financ. Manage., 31 (2), 33-45. 
Huang, Wei. Jiang, Fuxiu. Liu, Zhibiao. Zhang, Min. 2010. Agency Cost, Top Executives' Overconfidence, and Investment-Cash Flow Sensitivity-Evidence from Listed Companies in China.SSRN Electron. $J$.

Iskandar. 2008. Educational and Social Research Methodology (Quantitative and Qualitative). Jakarta: GP Press.

Jensen, MC, \& Meckling, WH (1976). Theory of the firm: Managerial behavior, agency costs and ownership structure. Journal of Financial Economics, 3 (4), 305-360.

Kahneman, D., Lovallo, D. 1993. Timid Choices and Bold Forecasts: A Cognitive Prespective on Risk Taking. Management Science, 39 (1), 17-31.

Liu, Zhigang. Mu, Congming. Wen, Chunhui. 2016. Impacts of Internal Financing on Investment Decisions by Managers with Cognition Biases. Journal of Mathematical Finance, 6, 431-442.

Malmendier, U., Tate, G., Yan, J. 2011. Overconfidence and Early-Life Experiences: The Effect of Managerial Traits on Corporate Financial Policies. J. Finance, 66 (5), 1687-1733.

Moez, El G., Amina, Zgarni. 2017. Overinvestment of Free Cash Flow and Manager's Overconfidence.International Business Research. 11 (3), 1913-9012.

Mohamed, Ezzeddine B., Fairchild, R., Bouri, Abdelfettah. 2014. Investment Cash Flow Sensitivity Under Managerial Optimism: New Evidence from NYSE Panel Data Firms. Journal of Economics, Finance and Administrative Science, 19, 11-18.

Murhadi, Werner Ria. 2018. Managerial overconfidence and firm financing decision: an Indonesian case. Advances in Social Science, Education and Humanities Research (ASSEHR), volume 186.

Qian, Wang. Liqian, Wu. Fengru, Xi. 2014. Study on the relationship between corporate governance and investment efficiency based on the analysis of Tsingtao brewery group in China. Bio Technology An Indian Journal, 10 (8), 2343-2348.
Richardson, Scott. 2006. Over-investment of free cash flow. Rev. Account. Study, 11, 159-189.

Rihab, Ben Atitallah. Jedidia, Lotfi Ben. 2016. Journal of Modern Accounting and Auditing, Vol. 12, No. 4, 225-241.

Copy, Ahmad Saiful Azlin Puteh. Nawawi, Anuar. 2018.nCorporate Governance And Investment Efficiency: Malaysian. Proceeding of INSIGHT 2018 1st International Conference on Religion, Social Sciences and Technological Education Evidence.

Silalahi, U. 2009. Social Research Methods. Bandung: PT RefikaAditama. P. 160.

Shefrin, H. 2001. Behavioral Corporate Finance. J. Appl. Corp. Finance, 14 (3), 113-124.

Shima, Keiichi. Nakamura, Jun-ichi. 2018. Managerial OverconÖdence, ConservativeAccounting and Corporate Investment.SSRN Electron. J.

Sugiyono.2008. Quantitative Research Methods, Qualitative and R \& D. Bandung: Alfabeta.

Sugiyono, Arief. 2009. Financial Management for Financial Practitioners. Jakarta: Grasindo.

Xia, WANG. Min, ZHANG. Fusheng, YU. 2009.

Managerial overconfidence and overinvestment: Empirical evidence from China. Front. Bus. Res. China, 3 (3): 453-469.

Yapono, DA, Khomsatun, S. 2018. The Role of Governance as Moderation on the Effect of Earning Management on Investment Efficiency. Journal of Accounting and Business Dynamics, Vol. 5 (2), 2018, pp 179194.

Zani, J., Leites, ET, Macagnan, CB, and Portal, MT 2013. Interest On Equity and Capital Structure In The Brazilan Context. International Journal Of Managerial Finance, Vol. 10 No. 1, p. 3953. 